\title{
Hydrochar as A Vehicle for Phosphorus Cycling from Dairy Manure to Cropland
}

\author{
B Brian $\mathrm{He}^{1 *}$ and Lide Chen ${ }^{2}$ \\ ${ }^{1}$ Chemical \& Biological Engineering, College of Engineering, University of Idaho, 875 Perimeter Drive MS 2060, Moscow, ID 83844, USA \\ ${ }^{2}$ Soil and Water Systems, Twin Falls Research and Extension Center, University of Idaho, 315 Fall Avenue East, Twin Falls, ID 83303, USA
}

*Corresponding author: B Brian He, Chemical \& Biological Engineering, College of Engineering, University of Idaho, 875 Perimeter Drive MS 2060, Moscow, ID 83844, USA.

\begin{abstract}
Dairy manure contains high concentrations of unutilized phosphorus which is not only a waste of resources but also a burden to dairy farmers and a threat to our environment. Phosphorus cycling and reuse would have a great impact on the dairy industry and agricultural economy as whole. Hydrochar possesses better biological properties when used for soil improvement and carbon sequestration. When produced from dairy manure, hydrochar can attain more than $90 \%$ of the total phosphorus content in manure and thus serves as an efficient vehicle for recycling nutrients from waste streams back to the crop system. Research findings prove that hydrochar from dairy manure is scientifically feasible and technologically promising as a vehicle for phosphorus recycling from waste to cropland.
\end{abstract}

\section{Introduction}

World consumption of $\mathrm{P}_{2} \mathrm{O}_{5}$ for fertilizer and industrial uses was 47 million tons in 2020 and the reserve of phosphorus rock was more than 300 billion tons [1]. Phosphorus rock is mainly found in sedimentary phosphate deposits and some as igneous phosphate deposits [2]. Although phosphorus cycles biogeochemically through the lithosphere, hydrosphere, and biosphere, its original source is non-renewable. Therefore, it is a logically wise strategy to utilize limited phosphorus reserves effectively and efficiently for generations to come.

The dairy industry provides quality food for our societies but also produces tremendous quantities of solid dairy manure. In the U.S., there were 8.86 million heads of milking cows in 2020 [3], which translates to over 240 million metric tons (530 billion pounds) of dairy manure generated annually, estimated based on lactating cows [3]. Phosphorus utilization by dairy cows is not in high efficiency $[4,5]$. The phosphorus produced in the dairy manure of a lactating cow is in the range of 77-95 $\mathrm{g}(0.17-0.21 \mathrm{lb})$ per day [4], which is equivalent to approximately 28-35 kg (62-76 lb) of phosphorus per year per cow or 248,000-310,000 metric tons (549-679 million pounds) of phosphorus by the 8.86 million cows in the U.S. in 2020. This is not only a waste of our limited resources but also creates a tremendous burden for dairy farmers and for our environment. Therefore, it would have a beneficial impact on agriculture, both dairy and crop systems, if the phosphorus can be even partially recycled from dairy manure and reutilized back to cropland.

Dairy manure contains nutrients that are needed by crop systems. However, nutrient reutilization of dairy manure through direct land applications as a fertilizer has long been deemed inefficient and imbalanced [6,7]. Soil near confined dairy operations can only uptake limited quantities of directly applied manure due to the major concern of nutrient leaching to surface and ground waters. Dairy manure, even after treatment by traditional lagoon systems, cannot be transported over long distances for nutrient distribution in an economically feasible way. Therefore, carefully designed ma- 
nure management and best practices must be instituted to ensure a healthy dairy economy while protecting our environment from possible pollution to surface and ground waters. This calls for alternative technologies and nutrient management strategies that handle dairy manure in an environmentally friendly and economically profitable manner for the dairy industry [8-11].

\section{Hydrochar via Hydrothermal Carbonization}

Hydrochar is a carbonaceous material produced thermochemically from organic matter or biobased resources. The specific production process of hydrochar is commonly known as hydrothermal carbonization (HTC). This is largely due to the fact that HTC is typically conducted in aqueous solutions under mediate temperature $\left(180-250^{\circ} \mathrm{C}\right)$ and autogenous pressures (1.5-4.5 $\left.\mathrm{MPa}\right)$ in an enclosed system $[12,13]$.

HTC converts organic matter in an oxygen-absent or oxygen-lean environment in aqueous slurries through a series of complex reactions of hydrolysis, condensation, dehydration and decarboxylation, of which the mechanisms are not yet completely understood [14-16]. Processing of biomass via HTC yields a solid hydrochar as the targeted product, along with a post-processing liquid stream containing various water-soluble components. Since HTC processing does not require dry matter as the feedstock, it is distinctively advantageous to process wet biomass, such as dairy manure, directly without pre-drying [17-19].

There is a major difference between what is commonly known as biochar and hydrochar. Biochar is the name mainly used for the byproduct of a fast pyrolysis process of biomass or the product purposely produced from biomass for various applications, requiring dry biomass as the feedstock [20-23]. Evidentially, biochar has totally different targeted applications, such as adsorbents for wastewater treatment and soil amendments and fertilizer [24,25].
Processed at different conditions, hydrochar possesses quite different properties from biochar [26]; therefore, its targeted applications are different. Hydrochar has less rigid physical structures compared to biochar from pyrolysis [20]and is thus easier to be biologically broken down once applied to soils to release its nutrients. When produced from manures, hydrochar typically possesses better biological properties for soil improvement and carbon sequestration [24].

\section{Hydrochar as a Vehicle for Phosphorus Cycling}

The potential of hydrochar as a vehicle for phosphorus cycling has been recognized by the research community $[27,28]$, and turning dairy manure to hydrochar has been an area of interest for many researchers [12,29-31].

In addition to its high nutrient content, the very fine particles of biomass processed biologically by animals make dairy manure an ideal feedstock for hydrochar production. It has been found that the solid content of feedstock for hydrochar production is not a pivotal factor in HTC processing [12]. This finding proves that dairy manure of low solid contents (e.g., 2-5\%) from manure flushing systems can be feasibly processed into hydrochar.

To explore the attainment of nutrients, especially phosphorus, in hydrochar derived from animal manures for potential nutrient cycling purposes, researchers have made quite an effort in all aspects of hydrochar production. Researchers at the University of Idaho have been studying the fundamentals of hydrochar production from dairy manure for nutrient cycling since 2014 and have conducted engineering research and development for technological evaluation of the process for practical realization. Their research has shown that hydrochar attains a large quantity of phosphorus from fresh dairy manure (Table 1 ).

Table 1: Carbon and nutrient attainment rates at different temperatures with $15 \%$ of solid content \& 60 min [12]

\begin{tabular}{|c|c|c|}
\hline \multirow{2}{*}{ Operating Temp. $\left({ }^{\circ} \mathbf{C}\right)$} & $\mathbf{R}_{\text {Carbon }}$ Attainment Rates (\%wt) & $\mathbf{R}_{\text {Phosphorus }}$ \\
\cline { 2 - 3 } & 61.4 & 83.5 \\
\hline 240 & 66.3 & 82.5 \\
\hline 220 & 69.8 & 92 \\
\hline 180 & 74.4 & 94.4 \\
\hline
\end{tabular}

It has been evidenced that hydrochar production can be achieved at a temperature as low as $180^{\circ} \mathrm{C}$ with $15-30$ min of reaction time, and the reaction time can be shortened greatly by raising the temperature to $250^{\circ} \mathrm{C}$. The retention rate of nitrogen in hydrochar is more sensitive to processing conditions than those of carbon and phosphorus, decreasing as the operating temperature increases and reaction time extends. This phenomenon might be due to the decomposition of proteins into amino acids which in turn transfer to liquid phase [12,29].

It was found that under higher temperatures (e.g., $250{ }^{\circ} \mathrm{C}$ ), the yield of hydrochar is $78.8 \%$ at $15 \%$ of solid content and $68 \%$ at $5 \%$ of solid content. In contrast, the hydrochar yield is approximately $86 \%$ at $5 \%$ and $2 \%$ of solid contents if the operating temperature is at $200^{\circ} \mathrm{C}$ or $180^{\circ} \mathrm{C}$ for $60 \mathrm{~min}[12]$.

It was concluded that hydrochar yield from dairy manure is governed by the combination of process parameters, including processing temperature, retention time and solid content of the feed manure. Further investigation of process optimization revealed that an optimal phosphorus attainment of $90 \%$ or higher in hydrochar can be achieved under a set of processing condition of $224{ }^{\circ} \mathrm{C}$ of processing temperature, 30 min of processing time and $9.6 \%$ of solid loading rate [32]. Although varying under different processing 
conditions, the phosphorus attainment rates in hydrochar can be as high close to $100 \%$ [32]. Thus, hydrochar has a greater potential of retaining the nutrient values carried over from dairy manures. This agrees with the conclusions by others $[31,33]$.

Phosphorus readily available to plants must be in water-soluble phosphates. However, among the total phosphorus in manure, inorganic phosphorus is soluble and mainly in the liquid fraction, and organic phosphorus in the solid fraction [5,34]. Approximately $73 \%$ of phosphorus in fresh livestock wastes are in organic form [35], such as phospholipids and phytic acids (inositol hexakisphosphate, $\mathrm{C}_{6} \mathrm{H}_{18} \mathrm{O}_{24} \mathrm{P}_{6}$ ), which requires microbial activities, such as phosphatases and phytase, to generate free phosphates that plants can utilize.

Hydrochar retains high levels of total phosphorus in manure Although more scientific studies are needed before one can have a clear picture of the fate of phosphorus in hydrochar, it has been found that the hydrochar production process via HTC alters chemically the organic phosphorus in manures into ortho-phosphates $[33,36]$.

Organic phosphates in the liquid are deposited into the solid hydrochar and all calcium phosphate phare converted to crystalline hydroxylapatite at $225^{\circ} \mathrm{C}$. It was believed that thermochemical processing is responsible for the transformation mechanisms in HTC. The affinity cation ions to phosphorus largely determine the phosphorus speciation evolution during HTC treatment [36]. It was also found that cation ions such as $\mathrm{Ca}, \mathrm{Al}$, and $\mathrm{Fe}$ that form precipitating phosphates may be the most important factor which in turn determines the potential of phosphate retainment in the solid phase. The phosphorus change through HTC is tremendously advantageous in converting the unavailable organic phosphorus for better crop utilization

In summary, phosphorus in dairy manure can be recycled via hydrochar through the HTC process. Hydrochar production from dairy manure not only provides an alternative way of manure management but also creates a value-added product for dairy farmers. Hydrochar is an excellent vehicle that attains the phosphorus in dairy manure and can be a phosphorus-rich fertilizer and soil amendment. In addition, hydrochar is also a way of carbon sequestration, contributing to the world-wide effort to alleviating global climate change. Phosphorus cycling and reuse would make a great impact on the dairy industry and agriculture as whole. Research findings prove that hydrochar from dairy manure is scientifically feasible. Further investigations into technological readiness are needed before hydrochar from dairy manure as a vehicle for phosphorus cycling becomes a reality.

\section{Acknowledgement}

This work was financially supported partially by the USDA National Institute of Food and Agriculture Hatch Project (Accession number 1012741) and the Idaho Agricultural Experiment Station (IDA01575)

\section{Conflict of Interest}

No conflict of interest.

\section{References}

1. USGS (2021) Phosphate Rock Statistics and Information. In Mineral Commodity Summaries.

2. E Desmidt, K Ghyselbrecht, Y Zhang, E Desmidt, K Ghyselbrecht, et al. (2015) Global phosphorus scarcity and full-scale P-recovery techniques - a review. J Critical Reviews in Envir Sci Technol 45(4): 336-384.

\section{USDA NASS (2021) Milk Production.}

4. USDA NRCS (2008) Chapter 4 Agricultural Waste Characteristics. In Part 651 - Agricultural Waste Management Field Handbook. USDA Natural Resources Conservation Service. Washington, DC, 20250.

5. G Toor, B Cade-Menun, J Sims (2005) Establishing a linkage between phosphorus forms in dairy diets, feces, and manures. J Environ Qual 34: 1380-1391.

6. J Elser, W Fagan, R Denno, D Dobberfuhl, A Folarin, et al. (2000) Nutritional constraints in terrestrial and freshwater food webs. Nature 408(6812): 578-580

7. V Sadras (2006) The N:PHOSPHORUSstoichiometry of cereal, grain legume and oilseed crops. Field Crops Research 95:13-29.

8. C Stallings, K Knowlton (2009) Strategies to reduce amounts of nitrogen and phosphorus in dairy rations. VCE Publications 404-130. Virginia Cooperative Extension, Virginia Tech.

9. R Maguire (2009) Impact of Changing from Nitrogen- to PhosphorusBased Manure Nutrient Management Plans. VCE Publications 422-310. Virginia Cooperative Extension, Virginia Tech.

10. National Research Council (NRC) (2016) Nutrient Requirements of Dairy Cattle. 7th ed. Natl Acad Sci, Washington, D.C.

11. Preston (2016) Feed composition table.

12. Z Bi, G Staggs, B He (2016) Nutrient cycling via hydrochar produced from dairy manure. Abstract \# 2429987. ASABE 2016 Annual International Meeting. July 17-20. Orlando, Florida.

13. S Zhang, X Zhu, S Zhou, H Shang, J Luo, et al. (2019) Hydrothermal carbonization for hydrochar production and its application. In Biochar from biomass and waste: fundamentals and applications. Ed Y Ok, D Tsang, N Bolan and JM Novak, pp. 275-294. ISBN: 9780128117293.

14. A Funke, F Ziegler (2010) Hydrothermal carbonization of biomass: a summary and discussion of chemical mechanisms for process engineering. Biofuels Bioprod \& Bioref-Biofpr 4: 160-177.

15. V Strezov, M Patterson, V Zymla, K Fisher, T Evans, et al. (2007) Fundamental aspects of biomass carbonisation. Journal of Analytical and Applied Pyrolysis 79: 91-100.

16. K Mochidzuki, N Sato, A Sakoda (2005) Production and characterization of carbonaceous adsorbents from biomass wastes by aqueous phase carbonization. Adsorption - Journal of the International Adsorption Society 11: 669-673.

17. C He, A Giannis, J Wang (2013) Conversion of sewage sludge to clean solid fuel using hydrothermal carbonization: hydrochar fuel characteristics and combustion behavior. Applied energy 11: 257-266

18. D Basso, F Patuzzi D Castello (2016) Agro-industrial waste to solid biofuel through hydrothermal carbonization. Waste management. 47: 114-121.

19. A Jain, R Balasubramanian, M Srinivasan (2016) Hydrothermal conversion of biomass waste to activated carbon with high porosity: A review. Chem Engr Journal 283: 789-805.

20. J Libra, K Ro, C Kammann, A Funke, N Berge, et al. (2011) Hydrothermal carbonization of biomass residuals: a comparative review of the chemistry, processes and applications of wet and dry pyrolysis. Biofuels 2: $89-124$

21. AV Bridgwater (2012) Review of fast pyrolysis of biomass and product upgrading Biomass \& Bioenergy 38: 68-94. 
22. R Brown, B del Campo, A Boateng, M Garcia-Perez, O Mašek (2015) Fundamentals of biochar production. In Biochar for Environmenta Management, Science, Technology and Implementation. Ed J Lehmann and S Joseph. 2nd Ed. Routledge, New York. ISBN: 978-0-415-70415-1.

23. M Aller (2016) Biochar properties: transport, fate, and impact. Critical Reviews in Environmental Science and Technology 46(14-15): 11831296

24. J Lehmann, M Rillig, J Thies, C Masiello, W Hockaday, et al. (2011) Biochar effects on soil biota - A review. Soil Biology \& Biochemistry 43: 1812-1836.

25. J Lehmann, S Joseph (2015) Biochar for Environmental Management Science, Technology and Implementation. (2nd Ed.) ISBN: 978-0-41570415-1. Routledge, Taylro \& Grancis Group. New York.

26. H Kambo, A Dutta (2015) A comparative review of biochar and hydrochar in terms of production, physico-chemical properties and applications. Renewable \& Sustainable Energy Reviews 45: 359-378.

27. A Tasca, G Mannarino, R Gori, S Vitolo, M Puccini (2020) Phosphorus recovery from sewage sludge hydrochar: process optimization by response surface methodology. Water Science and Technology 82(11) 2331-2343.

28. C Aragón-Briceño, A Pozarlik, E Bramer, L Niedzwiecki, H PawlakKruczek, et al. (2021) Hydrothermal carbonization of wet biomass from nitrogen and phosphorus approach: a review. Renewable Energy 171: 401-415.

29. B He, L Chen (2020) Nutrient Cycling via Hydrochar. Abstract at the Virtual PNW and Mountain West Regional Conference on Nutrient Cycling, Soil Health \& Food Safety. Oct. 27-29.
30. K Wu, Y Gao, G Zhu, Q Yuan, Y Chen, et al. (2017) Characterization of dairy manure hydrochar and aqueous phase products generated by hydrothermal carbonization at different temperatures. Journal of Analytical and Applied Pyrolysis 127: 335-342.

31. S Heilmann, J Molde, J Timler, B Wood, A Mikula, et al. (2014) Phosphorus reclamation through hydrothermal carbonization of animal manures. Environ Sci Technol 48(17): 10323-10329.

32. B He, Z Bi, L Chen (2021) Optimization of process parameters for phosphorus attainment in hydrochar. (manuscript in preparation).

33. H Huang, C Fang, X Lu, R Jiang, Y Tang (2017) Transformation of phosphorus during (hydro)thermal treatments of solid biowastes: reaction mechanisms and implications for PHOSPHORUSreclamation and recycling. Environ Sci Technol 51(18): 10284-10298.

34. A Wolf, PHOSPHORUSKleinman, A Sharpley D Beegle (2005) Development of a water extractable phosphorus test for manure: an interlaboratory study. Soil Sci Soc Am J 69: 695-700.

35. USDA NRCS (2012) Chapter 3 Agricultural Wastes and Water, Air, and Animal Resources. In Part 651 - Agricultural Waste Management Field Handbook. USDA Natural Resources Conservation Service. Washington, DC, 20250.

36. H Huang, C Fang, X Lu, R Jiang, Y Tang (2018) Transformation of phosphorus speciation during (hydro)thermal treatments of animal manures. Environ Sci Technol 52: 3016-3026. 